\title{
Ricardo Palma y la cultura nacional
}

\author{
Por Miguel Ángel Rodríguez Rea
}


Doctor en Literatura. Profesor principal de la Universidad Nacional Mayor de San Marcos. Actual director de la Editorial Universitaria de la Universidad Ricardo Palma. 
Ya avanzado el siglo XXI, es evidente que los hechos y las ideas en las que Palma participó en el XIX están superados, pero le sobreviven su arte, su "magia verbal" y el fresco fascinante de sus Tradiciones peruanas, cinceladas como una soberbia Comedia humana ${ }^{2}$.

Es necesario juzgar a Palma desde estas dos dimensiones, una estrictamente estética y otra de testimonio de las épocas del devenir histórico-cultural del país. Una lectura contemporánea tiene que ofrecerle esta recepción pues su presencia en la literatura y la cultura peruana es un hito, además, por su originalidad creativa. Solo comparable a sus antecesores (el Inca Garcilaso y Felipe Guamán Poma) o a sus continuadores (César Vallejo, José María Arguedas y Mario Vargas Llosa).

La juventud debe acudir a sus páginas, no por el hecho simple de leer a un autor consagrado por generaciones heterogéneas de lectores, sino por el caudal de sentimientos e ideas que suscitan sus relatos.

Pues, la cultura es un tejido fino y complejo de interrelaciones entre la naturaleza física y la del ser humano, imposibles de separar para obtener la clave de su nacimiento y desarrollo.

1 Alberto Escobar, "La magia verbal de Ricardo Palma", Eco, Bogotá. Vol. IV, N 1, 1961: 20-40.

2 Alberto Flores Galindo, "Las Tradiciones: una Comedia humana", Revista. Universidad Ricardo Palma. No 5, dic. 1982: 138-140. 
Por eso, la mayoría de sus célebres tradiciones tienen su fuente de origen en textos leídos o tomados de la tradición oral, y organizados en torno a nuestro acervo cultural.

El trasunto cultural de Palma está construido de aquello que, al parecer, es material ancilar, marginal. Y ese es precisamente su acierto: darle preeminencia a lo que por norma general es prescindible. Sean hechos históricos notables o aventuras de personajes de escaso rango social, Palma diseña con esta materia prima una narrativa que va más allá de la literatura y de la historia.

Pocos escritores asumen el papel de ser cronistas de anécdotas con una visión ecuménica. La realidad que presenta se puede cotejar, pero la psicología de sus personajes tiene vida propia, que es difícil desentenderse de ellos luego de su lectura. Nos atrapa su contenido que rebasa la casualidad de lo fabulado.

La idiosincrasia del hombre que habita este territorio llamado Perú, está descrita en cada circunstancia que desafía a una realidad física y humana, a la par difícil y apasionante. En este sentido, no hay calco ni copia de la retórica española vigente de su época. Existe una voluntad de que sus Tradiciones reflejen el pequeño o el gran mundo de sus personajes: sus intereses mezquinos, sus espíritus chatos. Su transcurrir cotidiano según como la vida los trata.

Por eso se explica esa galería variopinta de personajes que encarnan cada uno de los atributos con que pueblan el mundo de contradicciones que son las Tradiciones. Una muestra indiscutible de períodos históricos inestables, amorfos, que buscan articularse social y culturalmente. Déficit que la sociedad peruana contemporánea no ha logrado superar. 
Eso explica que la sociedad inserta en las Tradiciones se la exhiba con sus grandezas y miserias. Con lo cual Palma enfrenta el reto que los intelectuales de su época tuvieron que sortear sin excusas. Pues revela, asimismo, a una nación en construcción: razón suficiente para que su obra perdure siempre lozana.

Es oportuno recordar que Palma es un clásico, entre otras virtudes porque gracias a su legado podemos vislumbrar la metamorfosis de la identidad nacional. Este aporte es de suyo inapreciable, teniendo en cuenta que la mejor literatura se nutre más de la vida que de la literatura. Por eso es que la actual juventud no debe pensar que Palma es un autor desvinculado del mundo actual. Porque si consideramos su lenguaje y su estilo literario, ya pasados de moda, no es ese el punto de conexión que se destaca, sino el vigor de sus ficciones para pensar en nuestro destino histórico.

Sus historias han calado en el imaginario nacional, lo cual es ya un reconocimiento unánime, natural en un clásico. A esta audiencia debe adicionarse la atención prestada por lectores de diversas disciplinas, que subrayan en Palma su interés por presentar al hombre peruano en todas sus facetas. 